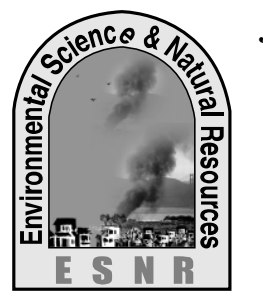

J. Environ. Sci. \& Natural Resources, 5(2): 307 - 313, 2012

ISSN 1999-7361

\title{
Progress and Prospect of Training on the Health and Quality of Seeds in Bangladesh
}

\author{
A. Q. M. B. Rashid, P. Dey and A. Sultana \\ Seed Pathology Center, BAU, Mymensingh
}

\begin{abstract}
Training on seed health was first initiated at the Seed Pathology Laboratory in the Department of Plant Pathology, BAU in 1880s. Farmers Block Supervisors and Subject Matter Specialists of DAE, Scientific Officers from SCA and Seed Wing Officers of BADC received the training. A total of 51 training programmes were conducted during the year 1988-2012 where 1003 trainees have been trained. The durations of the training courses ranged from one day to three months depending on the category of trainees. From 2006 to 2010 SPC organized training of six batches for the Post Graduate Certificate courses based on Seed Technology integrated with Seed Pathology. Through training programmes the knowledge and skills of the trainees were evaluated and found eventually changing their attitudes as regards to the health and quality of crop seeds.
\end{abstract}

Key words: Training, Seed health, Seed quality

\section{Introduction}

In the modern technological age training is an indispensable process for proper development of skills, efficiency and quality at all levels of a given profession (Bazlur Rashid, 2006). Besides, there is no alternative of training for the applied field of modern agricultural practices which play a significant role in the national economy of agro-based Bangladesh. Seeds are by far the single most essential cultivable source and prerequisite vital input in all crop-based worlds' food production for humans and their domesticated animals. But being the most efficient and effective carrier even a pure viable high yielding variety of seed is of little or no use to the grower if the seed carries inoculum of a dangerous seed borne pathogen which under favorable storage and field conditions may incur great threat to production. With the sustained rate of ever increasing population growth and the crying need perspective to the national objectives the balance and sustainable growth of crop production in agro-based Bangladesh is lacking. The use of low quality unhealthy seeds and the impact of seed borne diseases are one of the major constraints towards maintaining the consistency of growth of the production sustainability (Bazlur Rashid and Fakir, 2000). Coincidentally, most of the major diseases affecting the major crops in the country are highly seed borne and seed Considering the enormous crop losses due to seed borne diseases, research and training on the subject have been initiated at first at the department of Plant Pathology, BAU during 1980s. Subsequently, with the co-operation of DANIDA the works have been shape through establishing an independent laboratory namely- Seed Pathology Laboratory (SPL) which was upgraded to Seed Pathology Centre (SPC). transmitted result the annual yield losses worth two hundred fifty million US dollars (\$250) (Bazlur Rashid et al. (1995). In this context it has become imperative to give proper emphasis on the health and quality issue of the seeds in the crop production technology.

Out of the total requirements only $5-6 \%$ seeds are produced by the different seed organizations with care but almost regardless of the health status. The rest of seeds are retained by the farmers and remain as uncertified and unknown quality outside the supervision of SCA. For the farmers seeds are not produced and collected in appropriate scientific technology rather these are the portions of grain cash crop harvested for their consumptions. However, the seed organizations in the country are still not so aware of the impact of unhealthy seeds which affect directly or indirectly the crop productivity and sustainable food security in the country. Apart from teaching and research various training programmes have also been organized time to time for the personnel of different tyres such as experts, officers and managers, BSs of DAE; SCA, BADC etc. including the farmers who are the real concerned stackholders.

\section{Objectives}

The main objectives of the trainings were to create awareness among the Govt. and Semi-Govt. personnel including farmers/ growers dealing with the seed production and procurement, plant protection and seed certification etc. on the seed diseases and seed-borne plant diseases affecting planting value as well as market value of the seeds. 


\section{TRAININGS}

Depending upon the level of stack holders various category of need based 1 day to 3 months trainings were organized. Generally the local farmers of Mymensingh districts and in service personnel from different agencies, public and private organization agencies related to seed production, process, and procurement etc. of the country received the trainings (Table-1).

Trainings on seed health, management of seed borne diseases and production of healthy seeds for the Specialists, Extension Officers, Block supervisors, Technicians, NGO personnel and Farmers have been organized. It may be mentioned that the training on seed health issue were initiated since the inception of
SPC at the department of Plant Pathology, BAU and the trainings were the first of its kind in Bangladesh.

\section{FARMERS TRAINING DURING 1995-2011}

During 16 years (1995 to 2011) Seed Pathology Centre arranged total 17 trainings for the total of 288 farmer trainees, out of which male farmers were 180 and female farmers were 108 (Table-1). The ratio of male and female farmers was 3:2. Among 17 trainings 3 trainings were conducted for female and 6 trainings were conducted for male farmer only. The durations of the trainings ranged from one day to three days depending as the funds for trainings.

Table 1. Farmers training conducted 1995-2011

\begin{tabular}{|c|c|c|c|c|c|}
\hline \multirow{2}{*}{$\begin{array}{c}\text { Sl } \\
\text { no. }\end{array}$} & \multirow[t]{2}{*}{ Date of Training } & \multirow[t]{2}{*}{ Number of days } & \multicolumn{2}{|c|}{ Number of trainees } & \multirow[t]{2}{*}{ Total trainees } \\
\hline & & & Male & Female & \\
\hline 1. & 13-15 June, 1995 & 3 & 18 & 0 & 18 \\
\hline 2. & 30 October - 1 November, 1995 & 3 & 0 & 20 & 20 \\
\hline 3. & 29-30 June, 1996 & 2 & 0 & 30 & 30 \\
\hline 4. & 23-25 July, 1996 & 3 & 0 & 20 & 20 \\
\hline 5. & 10-12 December, 1996 & 3 & 9 & 11 & 20 \\
\hline 6. & 14-15 December, 1997 & 2 & 19 & 0 & 19 \\
\hline 7. & 29-31 March, 1998 & 3 & 15 & 1 & 16 \\
\hline 8. & 19 July, 1998 & 1 & 15 & 0 & 15 \\
\hline 9. & 11 December, 1999 & 1 & 12 & 0 & 12 \\
\hline 10. & 2 January, 2000 & 1 & 15 & 0 & 15 \\
\hline 11. & 19 June, 2000 & 1 & 9 & 0 & 9 \\
\hline 12. & 9 December, 2000 & 1 & 10 & 0 & 10 \\
\hline 13. & 19 February, 2004 & 1 & 9 & 3 & 12 \\
\hline 14. & 29 September, 2005 & 1 & 8 & 4 & 12 \\
\hline 15. & 7 June, 2010 & 1 & 16 & 4 & 20 \\
\hline 16. & 30 December, 2010 & 1 & 13 & 7 & 20 \\
\hline 17. & 15 September, 2011 & 1 & 12 & 8 & 20 \\
\hline \multicolumn{3}{|c|}{ Total } & 180 & 108 & 288 \\
\hline
\end{tabular}

\section{Training under $S P L$}

SPL developed and offered seed pathology courses based on those 12 years of experience and field demand expressed by the concern recipient agencies
(Table 2). Besides these training courses were designed for farmers (contract seed growers especially). 
Table 2. Training courses offered by SPL

\begin{tabular}{|l|l|l|l|l|}
\hline \multicolumn{1}{|c|}{ Category } & \multicolumn{1}{|c|}{ Trainees } & $\begin{array}{l}\text { Coordinating } \\
\text { Agency }\end{array}$ & Duration & \multicolumn{1}{c|}{ Curriculum/topics/subject } \\
\hline A. & Farmers, Female farmers & $\begin{array}{l}\text { BAUEC } \\
\text { BAU }\end{array}$ & $2-3$ days & $\begin{array}{l}\text { Importance of Seed Health, Orientation to } \\
\text { Seed-borne diseases, Production of disease } \\
\text { free seeds, Safe storage of seeds/rice/wheat } \\
\text { Jute/vegetables }\end{array}$ \\
\hline B. & $\begin{array}{l}\text { Block supervisors, Field assistants and } \\
\text { School teachers (Agri) }\end{array}$ & $\begin{array}{l}\text { BAUEC } \\
\text { BAU }\end{array}$ & 5 days & Same \\
\hline C. & $\begin{array}{l}\text { Overseers of Hort. Centre, Farm } \\
\text { Superintendent, Manager SM Farms } \\
\text { (BADC), and Seed Treaders }\end{array}$ & $\begin{array}{l}\text { GTI } \\
\text { BAU }\end{array}$ & $5-7$ days & $\begin{array}{l}\text { Economic importance of seed health, } \\
\text { Production processing and storage of disease } \\
\text { free seeds of rice, wheat, jute and vegetables }\end{array}$ \\
\hline D. & $\begin{array}{l}\text { Seed Analyst, Quarantine Inspector and } \\
\text { Lab. Technician }\end{array}$ & $\begin{array}{l}\text { GTI } \\
\text { BAU }\end{array}$ & 7 days & $\begin{array}{l}\text { Orientation to seed health, seed-health } \\
\text { testing techniques. }\end{array}$ \\
\hline E. & $\begin{array}{l}\text { In-service personnel of DAE, (SMS, } \\
\text { Horticulturist, SMO, Asstt. } \\
\text { Horticulturist) BADC and SCA }\end{array}$ & $\begin{array}{l}\text { GTI } \\
\text { BAU }\end{array}$ & 7 days & $\begin{array}{l}\text { Importance of seed-health, seed-crop } \\
\text { production techniques, Monitoring and } \\
\text { management of crop losses in the field and } \\
\text { storage. }\end{array}$ \\
\hline
\end{tabular}

Number of Trainees: Max. 20 for each training programme

\section{TRAININGS CONDUCTED DURING 2000 TO} 2012 UNDER SPC

A total of 17 training programmes were conducted at SPC during 2000-2012 (Table 3). Among these 9 trainings were organized for the farmers, 2 for the specialists and 6 for the University teachers, BADC officers, BARI officers and officers from NGOs.

Table 3. Summary of the trainings conducted at SPC during 2000 to 2012

\begin{tabular}{|c|c|c|c|c|c|}
\hline Sl. No. & Title of the training & Opening date & Closing Date & $\begin{array}{l}\text { No. of } \\
\text { training }\end{array}$ & Source of fund \\
\hline 01. & $\begin{array}{l}\text { Identification of seed borne diseases of boro } \\
\text { rice and their management }\end{array}$ & 02-01-2000 & 02-01-2000 & 15 & DANIDA \\
\hline 02. & $\begin{array}{l}\text { Management of seed borne diseases of rice, } \\
\text { Pilot Project Research, Amam } 2000 .\end{array}$ & $19-06-2000$ & $19-06-2000$ & 9 & DANIDA \\
\hline 03. & $\begin{array}{l}\text { Management of seed borne diseases of wheat } \\
\text { (Pilot Project Research, 2000-2001). }\end{array}$ & $09-12-2000$ & $09-12-2000$ & 10 & DANIDA \\
\hline 04. & Applied Seed Pathology & $07-04-2001$ & $16-04-2001$ & 15 & PROSHIKA \\
\hline 05. & Seed Health Technology & 09-12-2001 & $11-12-2001$ & 12 & DAE \\
\hline 06. & $\begin{array}{l}\text { Seed health, identification of seed borne } \\
\text { diseases and their mangement. }\end{array}$ & 19-02-2004 & 19-02-2004 & 12 & SPC, BAU \\
\hline 07. & $\begin{array}{l}\text { Seed health, identification of seed borne } \\
\text { diseases and their mangement. }\end{array}$ & 29-09-2005 & $29-05-2005$ & 12 & SPC, BAU \\
\hline 08. & $\begin{array}{l}\text { Post Graduate Certificate Course on Seed } \\
\text { Technology }\end{array}$ & $25-03-2006$ & $25-06-2006$ & 20 & SPC, BAU \\
\hline 09. & $\begin{array}{l}\text { Post Graduate Certificate Course on Seed } \\
\text { Technology }\end{array}$ & $15-07-2006$ & 15-09-2006 & 20 & SID/DANIDA \\
\hline 10. & $\begin{array}{l}\text { Post Graduate Certificate Course on Seed } \\
\text { Technology }\end{array}$ & $15-04-2007$ & $15-07-2007$ & 20 & SID/DANIDA \\
\hline 11. & $\begin{array}{l}\text { Post Graduate Certificate Course on Seed } \\
\text { Technology }\end{array}$ & 06-01-2008 & 06-04-2008 & 20 & SID/DANIDA \\
\hline 12. & $\begin{array}{l}\text { Post Graduate Certificate Course on Seed } \\
\text { Technology }\end{array}$ & 10-01-2009 & 10-04-2009 & 20 & SID/DANIDA \\
\hline 13. & $\begin{array}{l}\text { Post Graduate Certificate Course on Seed } \\
\text { Technology }\end{array}$ & 05-01-2010 & 04-04-2010 & 20 & SID/DANIDA \\
\hline 14. & Seed quality and seed health test & $07-06-2010$ & $07-06-2010$ & 20 & SPC, BAU \\
\hline 15. & $\begin{array}{l}\text { Seed health and quality test of winter } \\
\text { vegetable seeds }\end{array}$ & $30-12-2010$ & $30-12-2010$ & 20 & SPC, BAU \\
\hline 16. & $\begin{array}{l}\text { Seed health and quality test of winter } \\
\text { vegetable seeds }\end{array}$ & $15-09-2011$ & $15-09-2011$ & 20 & SPC, BAU \\
\hline 17. & Productin and storage of healthy seed & $23-05-2012$ & $23-05-2012$ & 25 & SPC, BAU \\
\hline
\end{tabular}


Training for specialists

A short course training 1-4 weeks long on seed health and seed technology for the specialists, technicians and contact growers of different seed organization were conducted at SPL with the cooperation of different organizations such as GTI, (BAU), BADC, SRTI, PRC etc. The totals of 40 courses were offered in each training. The trainees were included experts, officers and managers of DAE (Plant Protection and Quarantine officers), SCA, BADC, SMO, SMSs, Block supervisors, contact growers etc from different organizations (Table. 4). Altogether 1044 trainees were trained through a total of 37 courses during 1977-88.

Table 4. A short course training on seed health integrated with seed technology for the specialists, technicians and contact growers of different seed organization

\begin{tabular}{|c|c|c|c|c|c|c|}
\hline $\begin{array}{c}\text { Seed health integrated } \\
\text { courses with Seed } \\
\text { Technology } \\
\end{array}$ & Year & $\begin{array}{l}\text { No. the } \\
\text { course }\end{array}$ & Duration & $\begin{array}{c}\text { Share of } \\
\text { SPC } \\
(\%) \\
\end{array}$ & $\begin{array}{l}\text { No. the } \\
\text { trainees }\end{array}$ & Participants \\
\hline Seed Technology & $1977-78$ & 2 & 2 weeks & 30 & 38 & Seed analyst field officer of SCA \\
\hline Seed Technology & $1980-82$ & 6 & $1-4$ weeks & 10 & 263 & $\begin{array}{c}\text { Farm manager supervisor and } \\
\text { contact growers of BADC }\end{array}$ \\
\hline $\begin{array}{l}\text { Potato seed Production, } \\
\text { Post-harvest technology }\end{array}$ & 1981-85) & 14 & $1-3$ weeks & $20-30$ & 375 & $\begin{array}{l}\text { Managers, Contact growers, } \\
\text { officers and specialists of BADC, } \\
\text { SCA and DAE(Ag. Ext) }\end{array}$ \\
\hline $\begin{array}{l}\text { Crop Production } \\
\text { Technology } \\
\end{array}$ & $1983-84$ & 3 & 2-4 weeks & $3-5$ & 100 & $\begin{array}{l}\text { SMOs, SMSs and School teachers } \\
\text { of DAE and Communities schools }\end{array}$ \\
\hline \multirow[t]{2}{*}{ Seed health technology } & 1988 & 3 & 1 week & 100 & 65 & $\begin{array}{l}\text { SMSs, BSs and PP Officers of } \\
\text { BADC }\end{array}$ \\
\hline & Total & 37 & & & 1044 & \\
\hline
\end{tabular}

- $\quad$ Out of total number of trainees 803,251 and 30 were specialists, technicians and farmers respectively.

\section{Farmers training}

The need oriented short training programmes (1-3 days) for the farmers on the seed health issue were conducted at SPC during 1995-2011 (Table-1). Altogether 288 male and female farmers received the training which were conducted as per need of the farmers regarding the production, storage and procurement based on both lab and field orientation. Out of which the maximum (180) were male trainees and the rests were the females (Fig.1).

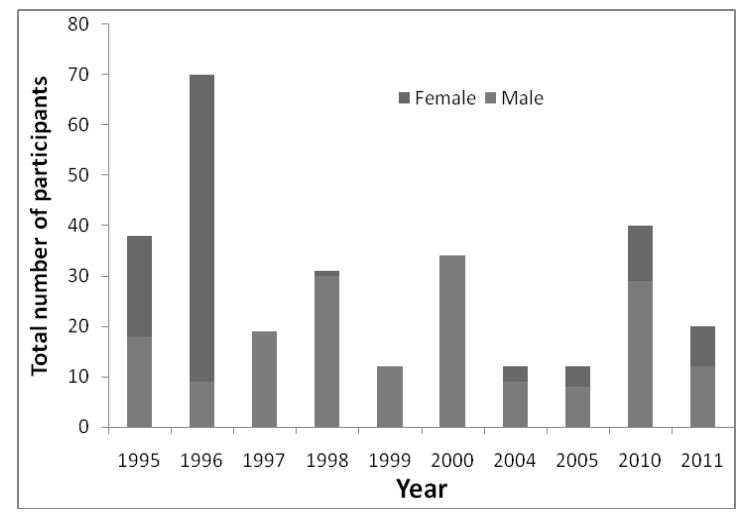

Fig 1. Farmers training on seed health conducted at SPC during 1995-2011 
All the trainings were actually followed in accordance with the training usually held at the Danish Govt. Institute of Seed Pathology (DGISP), Presently, The Danish Seed Health Centre for Developing Countries-DSHC), founded in 1967 by Dr. Paul Neergaard. This is the first research organization in the world to work exclusively with the seed-borne diseases and so far 560 scientists and technologists from 72 developing countries have received Seed Pathology training (http://www.dshc.life.ku.dk/About/History.aspx).

\section{SUMMARY OF TRAININGS OFFERED DURING 1988-2012}

A total of 51 training courses were conducted for the officers and experts, block supervisors, Technicians and Farmers. A total of 1003 trainees received training in Seed Pathology Centre (Table-5).

Table 5. Summary of Trainings conducted during 1988-2012

\begin{tabular}{|c|c|c|}
\hline Trainees & No. of Trainings & Number of Trainees \\
\hline Experts \& officers & 13 & 214 \\
\hline Block supervisors & 13 & 237 \\
\hline Farmers Total & 25 & 552 \\
\hline T1 & $\mathbf{1 0 0 3}$ \\
\hline
\end{tabular}

\section{TRAINING ON SEED HEALTH INTEGRATED} WITH SEED TECHNOLOGY

Seed Pathology is very much integrated part of seed technology. Therefore three months duration Postgraduate Certificate course on Seed Technology and
Seed Pathology was conducted by SPC from 2006 to 2012 though 1-6 batches. Among six batches $1^{\text {st }}$ and $2^{\text {nd }}$ batches was conducted in 2006. Total 120 participants were trained (Table-6) where 19 were female participants.

Table 6. Post Graduate Certificate Course on Seed Technology conducted by SPC (2006-2010)

\begin{tabular}{|c|c|c|c|c|c|}
\hline Number of Batch & $\begin{array}{c}\text { No. of Trainings } \\
\text { /Year }\end{array}$ & \multicolumn{2}{|c|}{ Trainings } & \multicolumn{2}{l|}{ Participants } \\
\cline { 3 - 6 } & & Period & Duration & Male & Female \\
\cline { 3 - 6 } & & & 3 months & 17 & 3 \\
\hline $1^{\text {st }}$ & $2 / 2006$ & 25 March - 25 June, 2006 & 3 months & 17 & 3 \\
\hline $2^{\text {nd }}$ & $1 / 2007$ & 5 April - 15 July, 2007, 2006 & 3 months & 16 & 4 \\
\hline $3^{\text {rd }}$ & $1 / 2008$ & 6 January - 6 April, 2008 & 3 months & 17 & 3 \\
\hline $4^{\text {th }}$ & $1 / 2009$ & 10 January - 10 April, 2009 & 3 months & 17 & 3 \\
\hline $5^{\text {th }}$ & $1 / 2010$ & 5 January - 4 April, 2010 & 17 & 3 \\
\hline $6^{\text {th }}$ & \multicolumn{2}{|c|}{ Total } & 101 & 19 \\
\hline
\end{tabular}

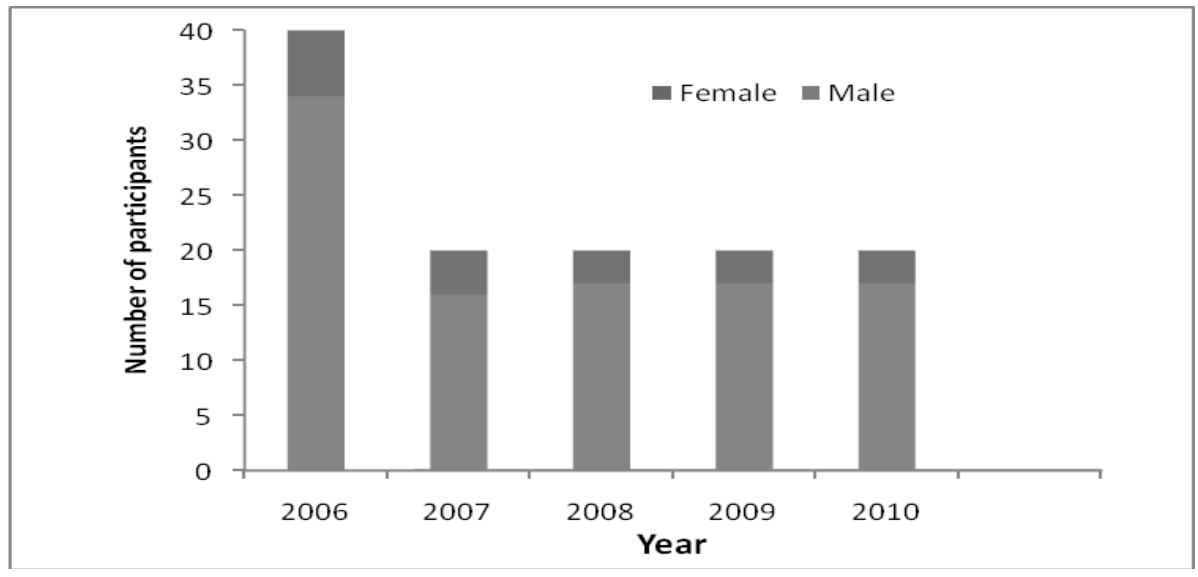

Fig 2. Three months training on seed health integrated with Seed Production and Technology for Post Graduate Certificate Course held at SPC during 2006-2010. 


\section{POST GRADUATE TRAINING}

Among all the trainings held at SPC some important ones were enlightened here as one of the progress of seed pathological activities in the country. Three months training on seed health integrated with Seed Production and Technology for the Post Graduate Certificate Course was held at SPC during 2006-2010 (Fig.2).

It is revealed that the maximum average participants (40 trainees) received the training in 2006 followed by 20 participants in each of the subsequent years. The highest number of male participants followed by the lower number participated every year though comparatively low in number. NATIONAL DEMAND FOR LONG COURSE TRAINING

However, it is understandable that except BAU, all the mentioned organizations have serious dark of personnel trained in Seed Pathology, (Table-7). The plant quarantine authority, the seed certification agency and the plant protection divisions are under DAE. These organizations under DAE need strong contingents of seed pathologists. Same is true for
BADC seed wing and the Plant Pathology divisions of the national Agricultural Research Organizations to meet their present and near future demand.

This is understandable that, given highest preference, it will not be possible for DGISP to provide training to one tenth of the estimated number of persons in this estimated period (Table - 6).

In front of this backdrop the SPL should manage to arrange long duration training programmes to respond to this national demand. The duration of the course may be six months two batches a year (as previously been offered by the DGISP) or nine months (as is being offered now in DGISP)- one batch a year. At the beginning 5-6 trainees may be accommodated per batch. Having said this, this must be also stated that, to enable SPL to undertake such venture wide range of multiple logistic supports must be provided to this infant organization. And to prepare SPL to take up major share of the long course training demand further local and foreign investment will be necessary.

Table 7. Demand for Systematic (Long Course) Training in Seed Pathology in Bangladesh.

\begin{tabular}{|c|c|c|c|c|c|c|}
\hline \multirow{2}{*}{ Areas } & \multirow{2}{*}{ Organizations } & \multirow{2}{*}{$\begin{array}{c}\text { Persons } \\
\text { trained at } \\
\text { (DGISP) }\end{array}$} & \multicolumn{4}{|c|}{ Personnel to be trained } \\
\hline & & & $\begin{array}{c}\text { Technicians/ } \\
\text { Frontline } \\
\text { Workers by } \\
2000 \text { AD } \\
\end{array}$ & $\begin{array}{l}\text { Additional } \\
\text { by } 2005 \mathrm{AD}\end{array}$ & $\begin{array}{c}\text { Specialists } \\
2000 \text { AD }\end{array}$ & $\begin{array}{l}\text { Additional } \\
\text { by } 2005 \mathrm{AD}\end{array}$ \\
\hline $\begin{array}{l}\text { Crop } \\
\text { production \& } \\
\text { protection }\end{array}$ & $\begin{array}{l}\text { DAE Crop } \\
\text { production wing } \\
\text { :Quarantine } \\
\text { service } \\
\text { :Seed } \\
\text { Certification } \\
\text { agency } \\
\text { Seed } \\
\text { multification } \\
\text { (Hort.) }\end{array}$ & $\begin{array}{l}1 \\
2 \\
2 \\
-\end{array}$ & $\begin{array}{l}20 \\
12 \\
8 \\
30\end{array}$ & $\begin{array}{l}60 \\
25 \\
15 \\
100\end{array}$ & $\begin{array}{l}15 \\
6 \\
4 \\
10\end{array}$ & $\begin{array}{l}50 \\
18 \\
10 \\
50\end{array}$ \\
\hline Research & $\begin{array}{l}\text { BARI } \\
\text { BRRI } \\
\text { BJRI }\end{array}$ & $\begin{array}{l}3 \\
2 \\
1\end{array}$ & $\begin{array}{l}10 \\
2 \\
2\end{array}$ & $\begin{array}{l}30 \\
10 \\
10\end{array}$ & $\begin{array}{l}10 \\
2 \\
2\end{array}$ & $\begin{array}{l}30 \\
10 \\
10\end{array}$ \\
\hline $\begin{array}{l}\text { Seed } \\
\text { multiplication } \\
\text { and trade }\end{array}$ & $\begin{array}{l}\text { BADC } \\
\text { BRAC (NGO) } \\
\text { PROSHIKA } \\
\text { (NGO) SEED } \\
\text { COMPANIES }\end{array}$ & 1 & $\begin{array}{l}10 \\
10 \\
10\end{array}$ & $\begin{array}{l}30 \\
30 \\
30\end{array}$ & $\begin{array}{l}10 \\
10 \\
10\end{array}$ & $\begin{array}{l}20 \\
15 \\
15\end{array}$ \\
\hline $\begin{array}{l}\text { Teaching Agri- } \\
\text { Colleges BAU }\end{array}$ & $\begin{array}{l}\text { Agricultural } \\
\text { Colleges } \\
\text { BAU/SPL Other }\end{array}$ & $\begin{array}{l}2 \\
7 \\
3\end{array}$ & $\begin{array}{l}4 \\
4\end{array}$ & $\begin{array}{l}8 \\
8\end{array}$ & $\begin{array}{l}2 \\
2\end{array}$ & $\begin{array}{l}8 \\
8\end{array}$ \\
\hline & & 24 & 122 & 356 & 83 & 244 \\
\hline
\end{tabular}




\section{FUTURE DEMAND FOR SHORT COURSE TRAINING}

The training courses, as being offered by SPC at present, have been proved beneficial to the organizations to which the trainees belong. Moreover the programmes have created high degree awareness and keen interest in the farmer's community. As a result, especially the organizations who deal with crop and seed production, distribution and trade are seriously demanding routine short course training programmes for their mangers, field staff, technicians and contact growers (farmers). As per information available to us at this moment, a number of 1479 technicians/front line workers and 439 specialists will need compact short-course training by the year 2014 (Table-8).These figures eventually may raise. It is evident that the SPC is quite well equipped with its technical facilities but organizational setup will be too little to carry out this task. For that matter restructuring of its organizational setup and continuous flow of fund assistance will be needed to be ensured.

Table 8. Personnel to be trained through compact short courses in seed health for an improved national programme, by the year 2014.

\begin{tabular}{|c|c|c|c|}
\hline \multirow{2}{*}{ Areas } & \multirow{2}{*}{ Organizations } & \multicolumn{2}{|c|}{ Personnel to be trained } \\
\hline & & Technicians/ Frontling Workers & Specialists 2000 AD \\
\hline $\begin{array}{l}\text { Agriculture } \\
\text { (Crops) }\end{array}$ & $\begin{array}{l}\text { a) Crop prodn. } \\
\text { b) Seed prodn. } \\
\text { c) Seed Process and storage } \\
\text { d)Seed trade } \\
\text { e) Agril. Service and } \\
\text { Extension } \\
\text { f) Pl. breeding }\end{array}$ & $\begin{array}{l}\text { Field Asstts. } 300 \\
\text { Contact Growers and Farmers } 600^{*} \\
\text { Asstt. Managers/Store Keepers } 60 \\
\text { Block Supers./Inspectors } 300 \\
\text { Technicians/ Field Asstts. } 60\end{array}$ & $\begin{array}{l}\text { Farms Suptdts.60 } \\
\text { Managers and Production } \\
\text { Specialist } 60 \\
\text { Supervisors/Managers } 60 \\
\text { Dealers/Managers } 20 \\
\text { Ext.Officers/Advisors/SMSs } 20 \\
\text { Plant Breeders } 20\end{array}$ \\
\hline $\begin{array}{l}\text { Teaching and } \\
\text { Training }\end{array}$ & $\begin{array}{l}\text { a) Agriculture and forestry } \\
\text { Training Institutions } \\
\text { b)Agril.Colledges/Universi } \\
\text { ties }\end{array}$ & $\begin{array}{l}\text { Lab. Technicians } 21 \\
\text { Lab. Technicians } 18\end{array}$ & $\begin{array}{l}\text { Instructors of Pl. Protection } 21 \\
\text { Teachrts of Pl. Path., Bot., Seed } \\
\text { Path., Pl.Breeding, Hort., Agron. } \\
\text { And Seed Technology } 18\end{array}$ \\
\hline Research & $\begin{array}{l}\text { a) Universities } \\
\text { b) Research Institutes and } \\
\text { c) Indust. Dev. Res. }\end{array}$ & Technicians and Field Attendants 60 & $\begin{array}{l}\text { Research } \\
\text { Scientists } 30\end{array}$ \\
\hline Control (Testing) & $\begin{array}{l}\text { a) Seed Testing } \\
\text { b) Seed Multipl. } \\
\text { c) Pl. Quarantine } \\
\text { d) Pl. Pesticide Testing }\end{array}$ & $\begin{array}{l}\text { Analysts, field Asstts. Techns. } 60^{*} \text { and } \\
\text { Inspectors }\end{array}$ & Scientists 30 \\
\hline & Total & 1479 & 439 \\
\hline
\end{tabular}

- Female participants will be preferred.

\section{References}

Anonymous, 1993. The Bangladesh Gazette April 8, 1993. Ministry of Agriculture, Section-12, No. Agricultue-12/Seed-110(2) 92/42, Date8.3 .

Bazlur Rashid, A.Q.M.; Fakir, G.A.; Mia, M.A.T. and Uddin, K. 1995. Seed health studies and crop production in Bangladesh. Journal of Sustainable Agriculture, 6 (2-3): 93-122.
Bazlur Rashid, A.Q.M.; Fakir, G.A. 2000. Impact of seed health on sustainable crop production in Bangladesh. Co-Operation, Journal of Co-Operative Sector, Bangladesh, pp. 24-36.

Bazlur Rashid, A.Q.M. 2006. A Training Evaluation on the Capacity Building for Open and Distance Learning Materials at Bangladesh Open University. J. of Agril. \& Rural Dev. 4(1\&2) : 27-33, 27-34.

http://www.dshc.life.ku.dk/About/History.aspx 